\title{
FELELŐSSÉG A JÖVŐÉRT - A KÖRNYEZETTUDATOSSÁG EGY MEGVALÓSULÓ ÁLOM?
}

\author{
RÉTHY ENDRÉNÉ \\ a Kodolányi János Főiskola Neveléstudományi Tanszék \\ főiskolai tanára \\ rethy@ludens.elte.hu
}

Kováts-Németh Mária „Az erdőpedagógiától a környezetpedagógiáig” című könyvét a jövőért vállalt felelősség hatja át. A kiadvány, mint ahogy a címe is tükrözi, nagy ívủ munka. Felöleli nagyszámú és jól szelektált forrásra támaszkodva a téma problématörténetét, a fogalmak, trendek változását. A szerző 19. század civilizációs ártalmaira adott ökológiai és pedagógiai válaszokból, törekvésekből kiindulva jut el napjaink fenntartható fejlődésének a pedagógiát is érintő kihívásaihoz. Elkészült munkája elsősorban nagyfokú szakértelmét és a téma iránti elkötelezettségét tükrözi. Kováts-Németh Mária ugyanis évtizedek óta fejti ki magas színvonalú nevelő-oktató tevékenységét részben a felsőoktatásban, részben az oktatásszervezés területén, s néhány éve a Nyugat-magyarországi Egyetem Doktori Iskolájában. Mindemellett mentora a ravaszdi erdei iskolának is. Legföképpen azonban szószólója a fenntartható fejlődés pedagógiájának.

A hét fejezet köré rendeződő ismeretanyag rendkívül gazdag, egymásra épülő interdiszciplináris megközelítést tükröző. Különösen jelentős a pedagógiai vonatkozások árnyalt, szakszerü bemutatása. Az első felismerésektől, a civilizációs ártalmakra adott pedagógiai válaszokból eredeztetett, majd a 20. század globális problémáira fókuszáló, végül napjaink fenntartható fejlődés kérdése köré kiteljesedő felelősség hatja át az egész munkát. A külföldi iskolapéldáktól a hazai iskolamodellekig bezárólag rengeteg új törekvés, próbálkozás, kísérlet történt az oktatás megújítására, $\mathrm{s}$ ezen belül a környezetvédelem fontos nevelési feladatainak előtérbe kerülése tekintetében. Ennek a folyamatnak a bemutatása rendkívül jelentős része a kötetnek.

Találkozhatunk a könyvben számos hazai és nemzetközileg elismert tudós állásfoglalásával, akik valamennyien jó korán felismerték a környezeti ártalmak veszélyeit. Említésre kerül a túlnépesedés, a gazdasági növekedés, az energiaforrások kimerítése, a civilizációs ártalmak, mint környezetkárosító faktorok. Olvashatunk jelentős nemzetközi egyezményekről, konferenciákról, melyek a környezet védelme céljából szerveződtek. Közülük talán az egyik legfontosabb az ENSZ égisze alatt szerveződő Fenntartható Fejlődés Világkonferencia 2002-ben, illetve az erre építkező „A fenntarthatóságra nevelés ENSZ EGB stratégiája” címü konferencia 2005-ben. 
A társadalmak tudatos klíma,- levegőtisztaság- és a természet védelmére irányuló konferenciák, egyezmények bemutatása is rendkívül fontos és plasztikusan megszerkesztett, szép összefoglaló táblázatokkal illusztrált részei a könyvnek.

Számunkra a legkiemelkedőbb fejezetek a pedagógiát érintő kérdések taglalásaként jelentkeztek. A hazánkat és egyáltalán a világot ért természeti katasztrófák drámai sora újfajta létmódot, megváltozott természetszemléletet tesz feltétlen szükségessé. E bonyolult helyzetben egyetlen erőforrás a jobb és több oktatás lehet, azaz a minőség biztosítása az elméleti és a gyakorlati képzésben, hangsúlyozza jogosan a szerző. Az értékközvetítés és minőségképzés, mint kiemelt pedagógiai feladat határozottan fogalmazódik meg a szerző koncepciójában. A környezettudatos nevelés szerepe a személyiség formálásában, fejlesztésében rendkívül nagy jelentőséggel bír. A tanulók gondolkodásában pedagógiai segítséggel azt a kognitív váltást teszi lehetővé, mely tudatosítja a környezetet kímélő, környezetvédő, felelős magatartás szükségességét. Fontos kiemelni a környezeti nevelés egymásra épülő szintereit, ahonnan talán tudatosan is kimaradt a család, annak diszfunkciós müködése okán az iskolára háruló feladatok megsokszorozódnak, s megnő a felelősség is e tekintetben. Bemutatja a munka többek között a magyarországi 22 ökoiskola hálózatának tevékenységét, valamint szerepét a környezettudatos magatartás kialakításában. A környezeti nevelés kitüntetett terepe a 80 -as évek végén újraszerveződő Erdei iskola, melynek bemutatása sokoldalú, árnyalt, $\mathrm{s}$ ami a legfontosabb, gyakorlatorientált is egyben. Az erdőpedagógiai projektek moduljainak ismertetése minta, modell lehet a ,jövő” iskolája számára. Elméleti koncepciója az a „harmóniaelmélet”, mely magában foglalja a testi-lelki egészség mellett a viselkedés- és környezetkultúrát. A gyakorlati kivitelezéshez a jó gyakorlat minőségéről is olvashatunk. A fenntarthatóság pedagógiája, a környezetpedagógia, mely a konstruktív életvezetés, a felelös magatartás interiorizálását szolgálja. Kialakításához a szerző átgondolt módon vázolja fel azt a tanulási folyamatot, mely elsősorban a projektoktatáson keresztül biztosítja az önszabályozott, motivált tanulást, az aktív, környezettudatos magatartás kialakulását a tanulókban. A környezettudatosság magába foglalja az ökológiai tudást, a környezeti értékek ismeretét, a cselekvési hajlandóságot, konkrét cselekvést a környezet érdekében. A felelős magatartás kialakításához mindenekelőtt felelősségtudat, önállóság, döntésképesség, szabadság szükséges, melyhez önkorlátozás, szabályok, normák betartani tudása, mértéktartás, segítőkészség, kompetencia kell hogy társuljon. Kitér az író a sajátos és hatékony tevékenységformák, tanulásszervezési eljárások, módszerek és eszközök ismertetésére. Ezzel a kötet nagyon fontos mondanivalója, célja nem csupán elméleti kifejtésen keresztül valósul meg, hanem nagyon erős oldala a gyakorlatorientált megközelítés is.

A müben kifejtett kérdések szakirodalmi háttere rendkívül gazdag, jól szelektált és strukturált. Az irodalomjegyzék ily módon figyelemre méltó, s egyben a további tájékozódás lehetőségét is hatékonyan szolgálhatja. E hiánypótló szakkönyv a jövő nemzedék természettudatos nevelődését úttörő módon segítheti azáltal, hogy 
az elmélet, azaz a környezettudomány és a neveléstudomány integrálásával és a belőle következő tudatos gyakorlat között felépíti a szükséges hidat. Így válik a munka a pedagógiai gyakorlatot orientáló, korszerü módszerekkel segítő, jól szemléltetett példaértékü fogódzóvá is egyben.

A kötet tele van a megértést és nem csupán az illusztrálást szolgáló gondosan elkészített, szerkesztett ábrákkal, táblázatokkal. Minden fejezet végén összefoglalás található. Hasznos a kötet végén szereplö Fogalomtár, mely alapos és körültekintő módon magyarázza meg a legfontosabb fogalmakat. Szükséges kiemelni a könyv esztétikai megjelenését is. Gyönyörü és méltó nyomdai produktumot vehet kezébe az olvasó. A keményfedelü, esztétikus borító szinte hívogató módon kínálja a belső tartalmat. Az egyes fejezeteket bevezető gondosan kiválasztott idézetek mívesek. Könyvészeti szempontból is kiemelkedő produktumról van tehát szó.

A könyv jelentős szerepet tölthet be a magyar pedagógiai szakirodalomban. Hatékonyan használható fel a mind a felsőoktatásban, mind pedig a szakmai továbbképzéseken. Jól forgatható és olvasásra ajánlható minden leendő pedagógus és már a gyakorlatban müködő tanár, tanító, valamint olyan, a téma iránt érdeklődő, a környezetet féltő, s azért tenni is akaró személy számára. Kívánatosnak találnám a könyv határon túli terjesztését is, hiszen globalizálódó világunkban a környezettudatos magatartás mindenki számára kötelező kellene hogy legyen!

Kováts-Németh Mária (2010): Az erdőpedagógiától a környezetpedagógiáig. Comenius Kft. Pécs, 350 oldal. 